\title{
KONSEP TATA KELOLA TEKNOLOGI INFORMASI UNTUK MENINGKATKAN LEVEL KEMATANGAN PADA SMPN DI KOTA LUBUKLINGGAU
}

\author{
Sepriadi $^{1 *}$, Dedy Syamsuar ${ }^{2}$, Linda Atika ${ }^{3}$ \\ Program Studi Magister Teknik Informatika, Universitas Bina Darma, Palembang 1,2,3 \\ e-mail: sepri_adi@hotmail.com ${ }^{1}$,dedy_syamsuar@ binadarma.ac.id ${ }^{2}$, \\ linda.atika@binadarma.ac.id ${ }^{3}$
}

\begin{abstract}
Abstrak
Saat ini SMP Negeri di Kota Lubuklinggau tidak dapat mengetahui pemanfaatan terhadap teknologi karena tidak memiliki dasar untuk mengetahui indikator yang dibutuhkan untuk memberikan ilustrasi dari hasil penerapan teknologi, yang menunjukkan kinerja teknologi infirmasi apakah telah sesuai dengan misi dan visi dari setiap SMP Negeri Kota Lubuklinggau. Dengan adanya permasalahan tersebut maka penulis akan melakukan penelitian untuk dapat melakukan proses tata kelola terhadap penerapan teknologi yang ada di SMP Negeri Kota Lubuklinggau. Framework COBIT 5 yaitu salah satu metodologi yang memberikan desain ataupun kerangka dasar dalam pemanfaatan serta penerapan sebuah teknologi yang memiliki kesesuaian terhadap kebutuhan organisasi, Framework COBIT 5 akan digunakan untuk melakukan tata Kelola Teknologi Informasi Negeri Kota Lubuklinggau. Pada penelitian ini penulis akan memilih empat domain dari beberapa domain di COBIT 5, domain ini terpilih karena memiliki kesesuaian untuk dapat dijadikan acuan untuk mengetahui maturity level teknologi yang telah diterapkan pada SMP Negeri Kota Lubuklinggau. Domain tersebut diantaranya yaitu APO07, EDM04, BAI08 dan APO01. Kesimpulan dari hasil penelitian yang telah dilakukan menunjukkan bahwa tingkat kematangan penerapan teknologi informasi yang telah dilakukan SMP Negeri Kota Lubuklinggau berada di level 1 dengan nilai 1.48, pada level ini menjelaskan bahwa teknologi informasi telah dilakukan secara Ad Hoc.
\end{abstract}

Kata kunci : Tata Kelola; Teknologi Informasi; COBIT 5; Maturity Level

\begin{abstract}
Currently SMP Negeri Lubuklinggau City cannot know the use of technology because it does not have a basis for knowing the indicators needed to provide an illustration of the results of the application of technology, which shows the performance of information technology whether it is in accordance with the mission and vision of each State Junior High School in Lubuklinggau City. With these problems, the authors will conduct research to be able to carry out the process of governance of the application of technology in SMP Negeri Lubuklinggau City. The COBIT 5 Framework is a methodology that provides a design or basic framework for the use and application of a technology that is suitable for organizational needs, the COBIT 5 Framework will be used to carry out the governance of State Information Technology in Lubuklinggau City. In this study the authors will select four domains from several domains in COBIT 5, this domain was chosen because it has the suitability to be used as a reference to determine the level of technological maturity that has been applied to SMP Negeri Lubuklinggau City. These domains include APO07, EDM04, BAIO8 and APO01. The conclusion from the results of the research that has been done shows that the maturity level of the application of information technology that has been carried out by SMP Negeri Lubuklinggau City is at level 1 with a value of 1.48, at this level it explains that information technology has been carried out in an Ad Hoc manner.
\end{abstract}

Keywords ; Governance; Information Technology; COBIT 5; Maturity Level 
I PENDAHULUAN

Kemajuan informasi teknologi berkembang pesat yang ditunjukkan pada tingginya minat masyarakat untuk mengumpulkan informasi melalui ketersediaan sistem informasi yang memadai. Ini karena informasi Teknologi dapat digunakan sebagai alat pengolahan data yang berperan untuk membantu organisasi dalam memproses, menyimpan dan mengubah data menjadi informasi [1] yang dibutuhkan pengguna. Pemanfaatan teknologi yang dinilai baik pada sebuah instansi penerintahan ataupun organisasi akan dapat meningkatkan efektivitas dan efisiensi kerja ataupun kegiatan operasional yang mereka lakukan. Terdapat manfaat yang juga dapat didapatkan yaitu dapat melakukan integrasi kerja dengan arah yang bebas. Integrasi tersebut dapat memberikan informasi dari berbagai pihak lain ataupun ke lokasi lain secara cepat. Instansi pendidikan merupakan lembaga yang berperan melakukan pengelolaan pendidikan untuk menyelenggaraan sistem pendidikan nasional agar proses pendidikan

dapat berlangsung sesuai dengan tujuan pendidikan [2].

Penulis melakukan langkah kajian penelitian sebelumnya yang dilakukan dari hasil penelitian berupa jurnal-jurnal yang telah penulis kumpulkan. Terdapat lima penelitian sebelumnya, yaitu sebagai berikut : Penelitian terdahulu terkait konsep tata kelola teknologi informasi untuk meningkatkan level kematangan seperti penelitian judul "Rekomendasi Tata Kelola Aset TI .

Berdasarkan COBIT 5". Membahas tata kelola TI yang dapat memberi nilai optimal terhadap penggunaan TI. Penelitian ini menggunakan framework COBIT 5 subdomain BAI09 dengan analisis tingkat kematangan menggunakan model PAM.
Hasil dari penelitian ini adalah mengetahui kondisi tingkat kapabilitas saat ini di SMK Kabupaten Madiun, yaitu rata-rata activity pada subdomain BAI09 berada pada level Performed Process [3].

Penelitian lain dalam bidang yang sama dengan penelitian judul "Optimalisasi Tata Kelola Teknologi Informasi Menggunakan COBIT 5 (Studi Kasus STT Pagar Alam)". Membahas optimalisasi tata kelola teknologi informasi di Sekolah Tinggi Teknologi Pagar Alam yang bertujuan untuk mendapatkan penilaian awal dari penerapan tata kelola teknologi informasi berdasarkan COBIT 5. Penelitian ini hasil nilai maturity level taat kelola teknologi informasi yang ada di Sekolah Tinggi Teknologi Pagar Alam saat ini menunjukan bahwa 9 domain mengarah pada level 2 (Repeatable) yaitu EDM04, APO01, APO04, APO07, BAI04, BAI10, DSS01, DSS03 dan MEA01. Hasil nilai maturity level saat ini menunjukan bahwa 2 domain mengarah pada level 3 (Defined) yaitu APO03 dan BAI09 [4].

Penelitian lain dengan penelitian judul "Model Konseptual Penerapan IT Governance Di Lembaga Keuangan Mikro Berbasis COBIT 5 Framework". Membahas seven enabler standar COBIT 5 digunakan sebagai kriteria dalam penerapan tata kelola teknologi informasi pada Lembaga Keuangan Mikro. Hasil dari penelitian ini berupa rekomendasi rancangan model konseptual bagi penerapan tata kelola teknologi informasi pada lembaga keuangan mikro dengan basis dokumentasi COBIT 5 [5].

Penelitian lain dengan penelitian judul "Pengukuran Capability Level Kualitas Layanan E-Government Kabupaten Pamekasan Menggunakan Framework COBIT 5.0". Penelitian yang bertujuan untuk melakukan audit dan evaluasi terhadap layanan E-Government Dispendukcapil Kabupaten Pamekasan pada Domain EDM dan APO. Hasil dari 
penelitian ini menunjukkan bahwa secara keseluruhan hasil audit capability level layanan TIK Dispendukcapil kabupaten Pamekasan berada pada level 3 (Establish) dengan nilai indeks capability level pada domain EDM 2,78 (establish) dan APO 2,50 (established) [6].

Penelitian lain dengan penelitian judul "Evaluasi Tata Kelola Infrastruktur TI Dengan Framework COBIT 5 (Studi Kasus: STMIK-STIE Mikroskil)". Penelitian yang bertujuan untuk mengevaluasi infrastruktur TI yang diadopsi dan digunakan oleh sekolah tinggi apakah telah memenuhi standar framework COBIT 5. Hasil dari penelitian ini menunjukkan STMIK-STIE Mikroskil memiliki beberapa hasil. Pertama, ada lima proses mencapai level 1 seperti EDM02, EDM04, APO04, BAI02, MEA01. Kedua, ada empat proses mencapai level 3 seperti EDM01, APO01, APO03, APO07. Ketiga, dan ada satu proses mencapai target level 4 seperti DSS05 [7].

Selanjutnya penelitian dengan penelitian judul "Pengukuran Tingkat Kematangan Tata Kelola TI Dengan Menggunakan Control Objective Plan And Organize Pada Framewrok COBIT Studi Kasus Sekolah Tinggi XYZ”. Penelitian yang bertujuan untuk mengukur tingkat kematangan tata kelola TI di Sekolah Tinggi XYZ. Hasil dari penelitian ini didapatkan hasil berupa tingkat kematangan exsisting Sekolah Tinggi XYZ sebgai berikut : PO1 tingkat kematangan 3, PO3 tingkat kematangan 3 , PO 7 tingkat kematangan 3 dan PO9 tingkat kematangan 2 [8].

Berdasarkan penelitian sebelumnya maka penulis menyimpulkan bahwa framework COBIT 5 merupakan model yang paling tepat dan telah banyak digunakan untuk meningkatkan level kematangan tata kelola teknologi informasi pada berbagai tempat penelitian yang mengimplentasikan teknologi informasi pada setiap kegiatannya.
Pada penelitian ini penulis melakukan pemetaan serta melakukan analisa domain hasil pemilihan domain dari framework COBIT 5 untuk mengetahui konsep yang dapat dijadikan acuan untuk dapat meningkatkan level kematangan teknologi informasi pada SMP Negeri Kota Lubuklinggau dengan melalui proses setelah tingkat kematangan saat ini dapat diidentifikasi sehingga menghasilkan gap kesenjangan yang berguna sebagai gambaran tingkat tata kelola teknologi informasi setiap sekolah Instansi pendidikan telah melakukan beberapa kegiatan untuk dapat mengoptiomalkan proses belajar mengajar. Teknologi informasi dapat memberikan manfaat yaitu dengan prinsip pembelajaran yang digunakan instansi pemerintahan untuk meningkatkan efisiensi dan efektivitas pembelajaran [9]. Pemanfaatan tenologi informasi menjadi kunci bagi sistem pendidikan nasional saat ini untuk dapat melakukan penjaminan dari keseluruhan pendidikan kepada setiap masyarakat yang dapat meningkatkan mutu serta relevansi serta efisiensi dari pengelolaan pembelajaran pada pendidikan yang dapat menjawab tatangan yang dituntut dapat terpenuhi pada perkebangan zaman saat ini dilingkungan nasional, global ataupun local sehingga peningkatan mutu pembelacara dilakukan secara terancana dan baik [10].

Sekolah Menengah Pertama Negeri Kota Lubuklinggau adalah salah satu jenjang pendidikan setelah sekolah dasar yang dibawah pengawasan dari dinas pendidikan kota Lubuklinggau. SMP Negeri kota Lubuklinggau tersebar dibeberapa kecamatan dengan jumlah sekolah sebanyak 15. Setiap SMP Negeri Kota Lubuklinggau dalam menjalankan operasionalnya membutuhkan teknologi untuk dapat memaksimalkan proses pembelajaran yang ada dilingkungan sekolah ataupun pada pendataan 
administrasi pada setiap sekolah. SMP Negeri Kota Lubuklinggau saat ini diketahui telah beberapa sekolah yang telah menerapkan teknologi pada seiap pembelajaran. Teknologi memiliki peranan penting yang dapat dimanfaatkan SMP Negeri Kota Lubuklinggau karena jika menanfaatan teknologi dapat dilakukan secara baik maka dapat dilaktakan untuk proses ataupun kegiatan pembelajaran dapat dilakukan dengan maksimal. SMP Negeri Kota Lubuklinggau tidak dapat mengetahui pemanfaatan terhadap teknologi karena tidak memiliki dasar untuk mengetahui indikator yang dibutuhkan untuk memberikan ilustrasi dari hasil penerapan teknologi, yang menunjukkan kinerja teknologi infirmasi apakah telah sesuai dengan misi dan visi dari setiap SMP Negeri Kota Lubuklinggau

Dari permasalahan tersebut maka penulis melakukan penelitian untuk dapat melakukan tata kelola TI terhadap penerapan teknologi yang ada di SMP Negeri Kota Lubuklinggau. Sehingga diharapkan penerapan TI yang ada dapat dimaksimalkan untuk lebih dapat meningkatkan proses kegiatan pembelajaran yang ada disekolah.

Tata keola TI merupakan salah satu kegiatan yang dinilai penting untuk organisasi ataupun instansi pemerintahan sehingga dapat melakukan perencanaan, pengendalian ataupun penerapan strategi untuk dapat memastikan teknologi dapat berjalan seimbang. Tata kelola yang baik yaitu jika penerapaan TI dapat dilakukan secara maksimal serta dapat diukur untuk mengetahui sejauh penilaian penerapan terhadap TI yang telah dilakukan [11].

Tata Kelola TI pada SMP Negeri Kota Lubuklinggau akan dilakukan dengan salah satu framework yang dapat menggambarkan tentang strategi ataupun peraturan yang ada pada setiap proses penerapan TI. Framework yang akan digunakan untuk melakukan tata kelola TI yaitu framework COBIT 5.

Definisi dari Framework COBIT 5 yaitu salah satu metodologi yang memberikan desain ataupun kerangka dasar dalam pemanfaatan serta penerapan sebuah teknologi yang memiliki kesesuaian terhadap kebutuhan organisasi. Setelah dilakukan tata kelola TI pada SMP Negeri Kota Lubuklinggau diharapkan akan dapat memberikan ilustrasi tentang bagaimana tingkat penerapaan teknologi yang telah ada tingkatan ini merupakan maturity level yang diharapkan akan dapat lebih ditingkatkan setelah proses analisis dilakukan.

\section{KAJIAN PUSTAKA}

\subsection{Tata Kelola Teknologi Informasi}

Untuk melakukan tata kelola TI di butuhkan kajian analisis khusus yang dapat berperan untuk menentukan keputusan teknologi informasi yang selama ini bersifat tidak dapat direncanakan dengan maksimal [13]. Hal tersebut ditunjukkan dari beberapa pernyataan yaitu sebagai berikut [13] :

1. Perdabatan informal untuk dapat menentukan keputusan

2. Penyelesaian tugas tata kelola TI dilakukan tanpa strategis khusus.

3. Tata kelola TI yang telah berjalan dinilai kurang karena terdapat $\mathrm{CIO}$ yang memiliki fokus yang lebih.

4. Untuk melakukan pemaparan ataupun komunikasi dinilai masih mengunakan bahasa technology minded.

5. Peran dari $C I O$ yang memiliki kelebihan akuntabilitas.

6. Permasalahan Teknologi informasi dikesampingkan karena lebih memeilih untuk fokus pada hal yang kecil.

\subsection{Kerangka Kerja COBIT}

Kerangka kerja COBIT adalah berbagai macam praktek terbaik dengan sifat genetik dimana sering menjadi salah satu pedoman untuk dapat memaksimalkan 
teknologi informasi berdasarkan sasasaran kendali dan proses Teknologi informasi yang dibutuhkan pada saat diterapkan [14].
Berikut ini gambar yang menunjukan kerangka kerja pada freamwork COBIT :

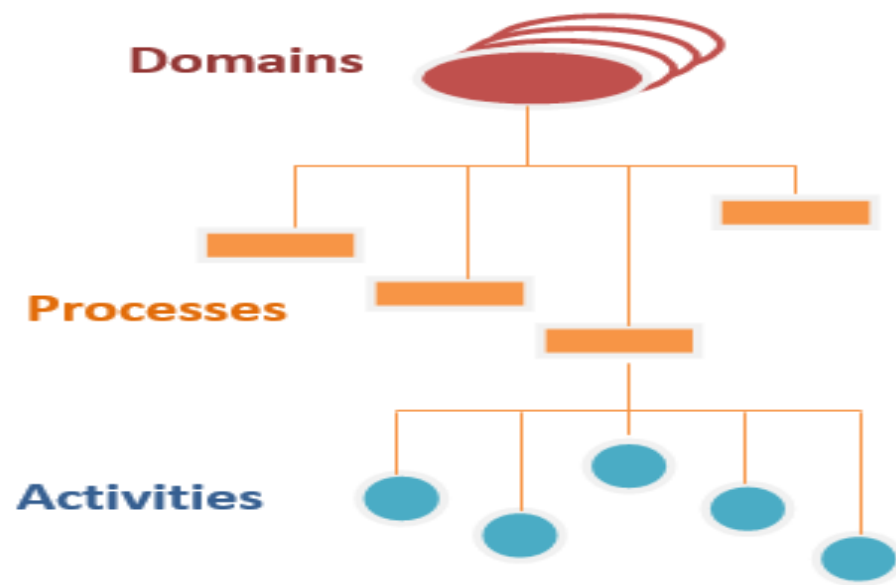

Gambar 1 kerangka kerja COBIT

Sumber : IT Governance Institute [15]

\section{$2.3 \quad$ COBIT 5}

COBIT 5 yaitu salah satu metodologi yang memberikan desain ataupun kerangka dasar dalam pemanfaatan serta penerapan sebuah teknologi yang memiliki kesesuaian terhadap kebutuhan organisasi.

Saat ini COBIT 5 digunakan sebagai dokumentasi yang dapat membantu penilaian Tata Kelola TI yang menggambarkan jarak antara kebutuhan kontrok, resiko dari bisnis serta permasalahan teknis pada TI. COBIT dapat digunakan untuk melakukan tata kelola untuk IT Governance [14]. COBIT memiliki 4 (empat) domain serta 34 (tiga pilih empat) high level control objectives, gambaran tersebut dapat dilihat pada gambar 2 dibawah ini [16] :

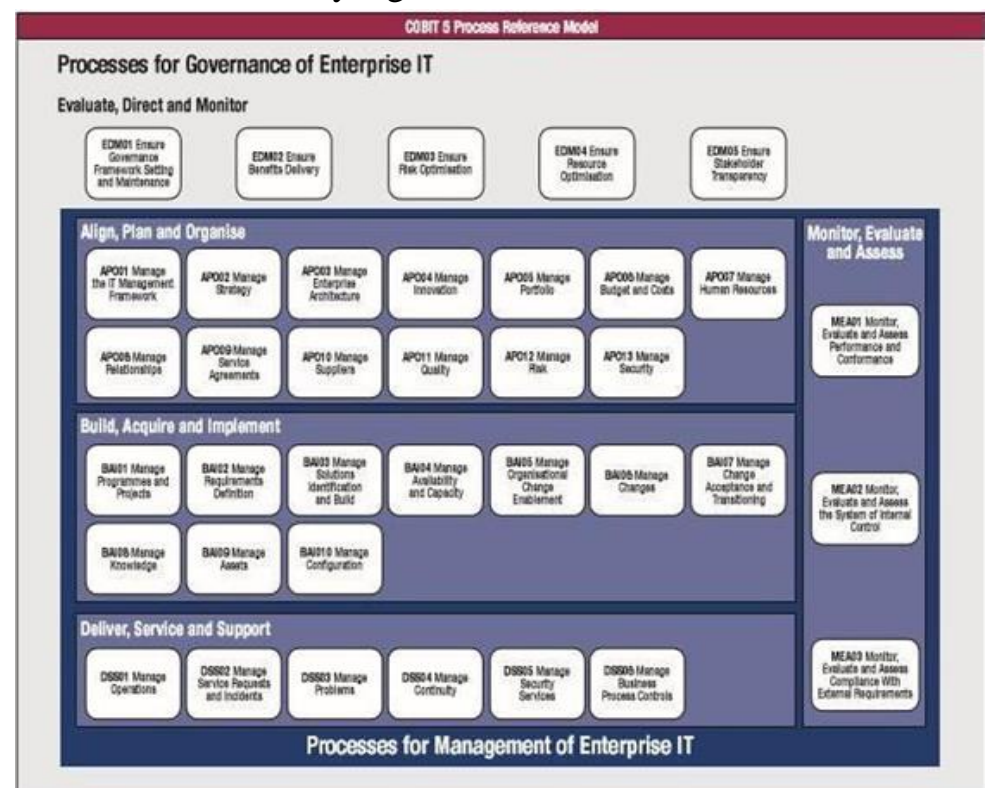

Gambar 2 COBIT Framework

Sumber : ISACA [16] 


\subsection{Model Kematangan}

Maturity Model atau model kematangan berguna untuk melakukan kontrol terhadap proses yang ada di Teknologi Informasi dengan memanfaatkan penilaian, penilaian tersebut akan menggambarkan organisasi berada pada level tertentu antara skala 0 sampai 5. Penjelasan tingkatan level kematangan dapat adalah sebagai berikut [17]:

Struktur kerangka kerja dalam COBIT dapat dijelaskan pada gambar berikut ini :

1. Level 0 (Non Existent) yaitu tingkat kematangan paling rendah dimana kondisi organisasi tidak melakukan penerapan Teknologi informasi sehingga tidak dapat dilakukan proses tata Kelola TI.

2. Level 1 (Initial) yaitu teknologi telah diterapkan dimana telah dilakukan perancanaan serta pengawasan terhadap tatata Kelola TI

3. Level 2 (Repeatable) yaitu organisasi memiliki kebuasaan dengan melakukan perencanaan dan megelola tata Kelola TI secara berulang tetapi belum memiliki prosedur dan dokumentasi tata keola TI.

4. Level 3 (Defined) yaitu organisasi telah melakukan prosedur dan mekanisme untuk tata Kelola TI dengan jelas serta tersosialisasi keseluruh jajaran manajemen.

5. Level 4 (Managed) yaitu organisasi telah melakukan penerapan pada beberapa indicator untuk melakukan pengukuran kinerja sehingga dapat melakukakukan monitoring pada pelaksanaan tata Kelola TI.

6. Level 5 (Optimalisasi) yaitu level tertinggi dimana pada level ini organisasi berhasil melakukan penerapan dengan baik terhadap penerapan teknologi yang mengacu pada prinsip best practise.

\section{METODOLOGI PENELITIAN 3.1 Desain Penelitian}

Gambaran pada proses penelitian akan ditunjukkan pada desain penelitian dimana tata kelola TI yang dapat berguna meningkatkan maturity level pada SMP Negeri Kota Lubuklinggau. Penelitian akan dilakukan berdasarkan identifikasi masalah yang di dapat selanjutnya melakukan studi pustaka tentang COBIT 5. Gambaran keseluruhan desain penelitian yang dapat dilihat pada gambar 3:

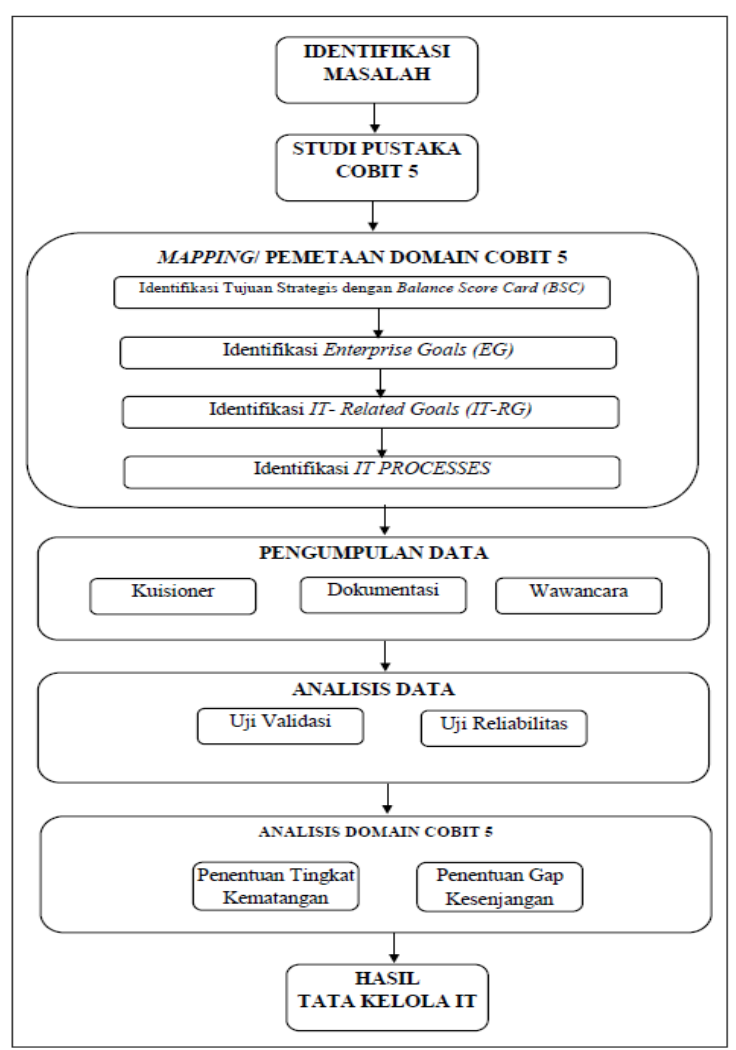

Gambar 3 Desain Penelitian

\subsection{Metode Penelitian}

Untuk melakukan analisis data hasil penelitian sehingga menghasilkan keterangan yang terkait dengan pada yang akan diketahui pada penelitian ini yaitu tingkat maturity level pada penerapan tata kelola TI di SMP Negeri Kota 
Lubuklinggau, analisis akan dilakukan dengan data kuantitatif dimana data analisis akan dilakukan dalam bentuk angka [18]. Pemilihan data kuantitatif karena hasil data penelitian yaitu jawaban responden dalam bentuk angka yang menjawab mengenai tata kelola TI pada SMP Negeri Kota Lubuklinggau.

\section{HASIL DAN PEMBAHASAN}

SMP Negeri Kota Lubuklinggau merupakan objek penelitian yang akan diteliti, dengan jumlah sekolah 15 SMP Negeri. Sampel untuk data penelitian merupakan orang yang terdapat pada didalam ruang lingkup sekolah yaitu terdiri dari 1(satu) Kepala sekolah, 1-2(satu sampai dua) guru, 1(satu) staff sekolah dan 3 (tiga siswa). Untuk subtotal setiap responden yaitu 15 kepala sekolah, 25 guru, 15 staf dan 45 siswa.

Identifikasi masalah penulis dapat setelah melakukan proses pengumpulan data, terdapat permasalahan yang penulis temukan yaitu SMP Negeri Kota Lubuklinggau tidak dapat mengetahui pemanfaatan terhadap teknologi karena tidak memiliki dasar untuk mengetahui indikator yang dibutuhkan untuk memberikan ilustrasi dari hasil penerapan teknologi, yang menunjukkan kinerja teknologi infirmasi apakah telah sesuai dengan misi dan visi dari setiap SMP Negeri Kota Lubuklinggau.

\subsection{Pemetaan dan Pemilihan Domain Framework COBIT 5 \\ Framework COBIT 5 diketahui}

telah memiliki alur untuk memilih serta melakukan pemetaan pada seluruh domain sehingga dapat terpilih domain yang dibutuhkan penulis untuk melanjutkan penelitian yang terkait dari tujuan strategis pada objek penelitian yaitu SMP Negeri Kota Lubuklinggau dalam hal optimalisasi untuk meningkatkan level kematangan pada.

Proses awal untuk melakukan pemilihan domain yaitu dengan melihat dari objektifitas tata kelola yaitu Resource Optimisation, diketahui bahwa sumber daya tersebut akan berkaitan dengan apa yang akan dituju pada penelitian. Pada penelitian ini tujuan utama untuk melakukan tata kelola TI yaitu mendapatkan serta mengetahui sejauhmana penerapan tata kelola sehingga yang diketahui dari maturity level. Setelah diketahuinya maturity level dapat memberikan grade meningkat dengan melakukan analisis lanjutan untuk lebih meningkatkan maturity level.

Setelah melakukan Resource Optimisation selanjutnya melakukan proses pemilihan $E G$ (enterprise goals) yang dilakukan berdasarkan pemetaan pada beberapa dimensi BSC (balance score card, proses seleksi dilakukan dengan penandaan dengan symbol $\mathrm{P}$ (Primary) pada resource optimization yang merupakan objek tata kelola.

Setelah melakukan proses pemilihan $E G$ (enterprise goals), selanjutnya dapat melakukan proses seleksi yang terdiri dari 14 (empat belas ) enterprise goals dan 17 (tujuh belas) ITrelated Goals yang telah terpilih dari hasil pemetaan untuk dilakukan seleksi pemilihan proses yang ada di COBIT 5 .

Selanjutkan akan dilakukan pemetaaan Kembali ke IT-related goals setelah sebelumnya mendapatkan hasil proses pemetaan IT-Related Goals. Hasil dari proses tersebut merupakan hasil akhir untuk selanjutnya dapat didukung dengan proses yang ada dalam COBIT 5, pemilihan proses akan disesuaikan dengan kebutuhan penelitian yaitu proses yang dapat menggambarkan maturity level di SMPN Kota Lubuklinggau.

Terdapat beberapa Domain proses dari COBIT 5 yang terpilih dan akan digunakan pada penelitian ini yaitu APO07, EDM04, BAI08 dan APO01. 
Domain proses yang terpilih tersebut selanjutnya akan dilakukan proses assessment, berikut ini pada tabel 1 akan menjelaskan deskripsi assessment dari beberapa domain proses yang terpilih :

Tabel 1 Proses COBIT 5 yang telah Assesment

\begin{tabular}{llr}
\hline Proses ID & EDM04 & \\
\hline Process & Memastikan & Optimalisasi \\
Name & Sumber Daya & \\
\hline Process & Memastikan & bahwa \\
Descriptio & kemampuan & yang \\
$n$ & berkaitan dengan TI \\
& memadai dari SDM,
\end{tabular}

proses serta teknologi serta tersedia untuk mendukung tujuan setiap sekolah menengah pertama negeri Kota Lubuklinggau.

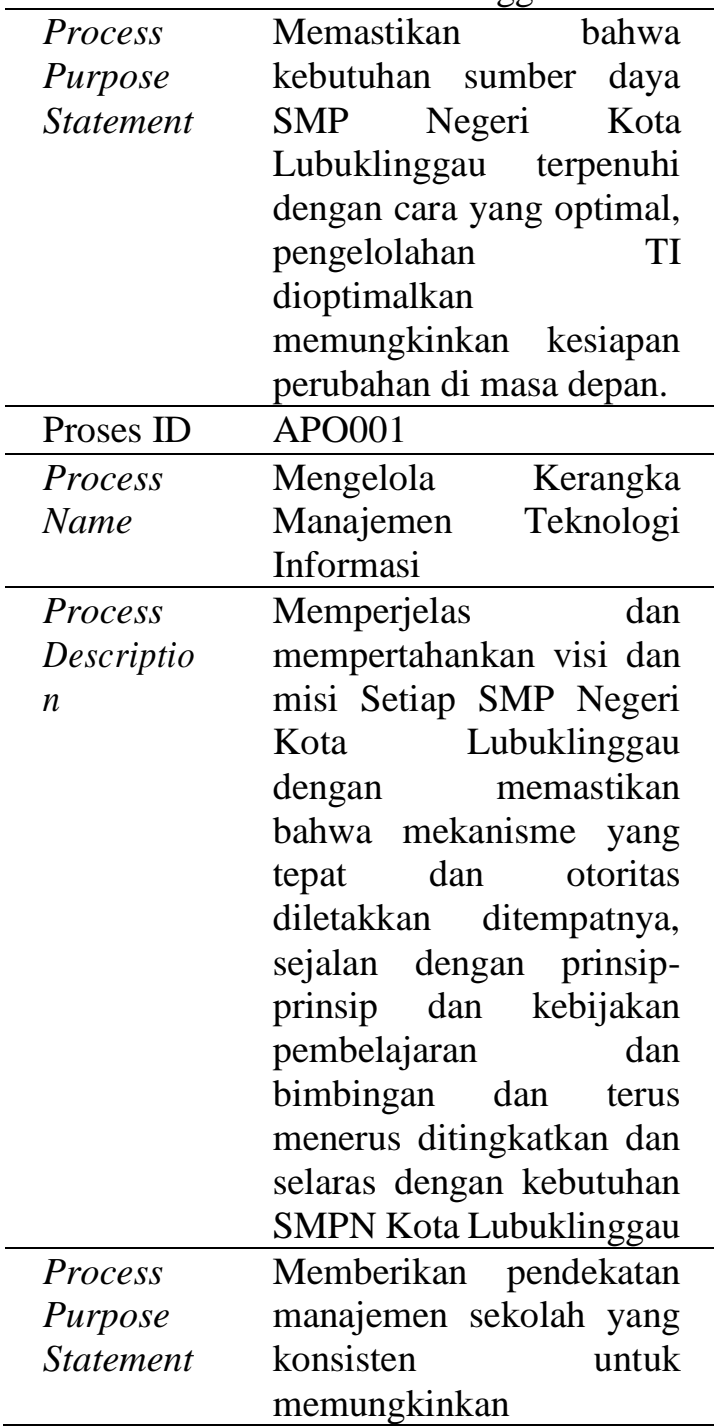

persyaratan tata kelola SMP Negeri Kota Lubuklinggau harus dipenuhi, meliputi proses manajemen sekolah, struktur organisasi, peran dan tanggung jawab serta keterampilan dan kompetensi.

\begin{tabular}{llr}
\hline Proses ID & APO007 & \\
\hline Process & Mengelola Sumber Daya \\
Name & Manusia & \\
\hline Process & Menyediakan & pendekatan \\
Descriptio & terstruktur & untuk \\
$n$ & memastikan & penataan
\end{tabular}

n penempatan, keputusan, dan keterampilan sumber daya manusia yang optimal yang termasuk dalam proses mengkomunikasikan peran dan tanggung jawab, rencana pembelajaran dan pengembangan, dan ekspektasi kinerja yang didukung oleh staf sekolah yang kompeten dan termotivasi.

Process Mengoptimalkan

Purpose kemampuan sumber daya Statement manusia untuk memenuhi tujuan SMPN Kota Lubuklinggau.

\begin{tabular}{ll}
\hline Proses ID & BAI08 \\
\hline Process & Mengelola Pengetahuan
\end{tabular}
Name

$\begin{array}{ll}\text { Process } & \text { Mempertahankan } \\ \text { Descriptio } & \text { ketersediaan dari }\end{array}$

$n \quad$ pengetahuan relevan, saat ini, yang sudah divalidasi dan dapat dipercaya untuk mendukung seluruh aktivitas proses dan memfasilitasikan pembuatan keputusan kegiatan sekolah.

Process Menyediakan pengetahuan

Purpose yang dibutuhkan untuk Statement mendukung seluruh guru dan staf dalam aktivitas pekerjaannya dan untuk menginformasikan 


\section{pembuatan keputusan dan meningkatkan produktivitas setiap SMP N Kota Lubuklinggau \\ Sumber : Hasil pengolahan data dan ISACA [16]}

\subsection{Analisis Uji Validitas dan Uji Reabilitas}

1. Analisis Uji Validitas

Pada tata kelola teknologi informasi akan dilakukan proses analisis Uji validitas yang berguna untuk dapat mengetahui instrument penelitian layak untuk dapat digunakan pada penelitian, sehingga dapat memberikan informasi gambaran dari kebenaran dari penyusunan instrument penelitian [19]. Dengan adanya uji validitas dapat memberikan nilai secara statistik dengan menghasilkan jawaban apakah setiap pertanyaan instrument penelitian yang digunakan teridentifikasi valid atau tidak valid untuk pengambilan data penelitian [20].

Dari hasil keseluruhan uji validitas menjelaskan bahwa hasil jawaban responden penelitian disetiap variabel dapat diidentifikasi valid berdasarkan pengolahan data menggunakan SPSS versi 21 dari 100 responden dengan nillai standar $r_{\text {tabel }}$ 0.195 .

Berikut merupakan rekapitulasi dari korelasi dan hasil uji validitas untuk setiap varibel yang dapat dilihat pada tabel 2 berikut ini:

Tabel 2 Rekapitulasi Hasil Uji Validitas

\begin{tabular}{cccl}
\hline $\begin{array}{c}\text { Variabel } \\
\text { Domain } \\
\text { Proses }\end{array}$ & $\mathrm{r}_{\text {hitung }}$ & $\mathrm{r}_{\text {tabel }}$ & Keterangan \\
\hline EDM04 & & & \\
D1_1 & 0.803 & 0.195 & Valid \\
D1_2 & 0.720 & 0.195 & Valid \\
D1_3 & 0.691 & 0.195 & Valid \\
D1_4 & 0.806 & 0.195 & Valid \\
D1_5 & 0.352 & 0.195 & Valid \\
D1_6 & 0.697 & 0.195 & Valid \\
\hline APO01 & & & \\
\hline
\end{tabular}

\begin{tabular}{cccc}
\hline D2_1 & 0.676 & 0.195 & Valid \\
D2_2 & 0.527 & 0.195 & Valid \\
D2_3 & 0.649 & 0.195 & Valid \\
\hline APO07 & & & \\
D3_1 & 0.811 & 0.195 & Valid \\
D3_2 & 0.752 & 0.195 & Valid \\
D3_3 & 0.718 & 0.195 & Valid \\
D3_4 & 0.683 & 0.195 & Valid \\
\hline BAI08 & & & \\
D4_1 & 0.744 & 0.195 & Valid \\
D4_2 & 0.633 & 0.195 & Valid \\
D4_3 & 0.731 & 0.195 & Valid \\
\hline
\end{tabular}

Sumber : Hasil pengolahan data

\section{Analisis Uji Reliabilitas}

Uji validitas pada tata kelola teknologi informasi digunakan untuk memperoleh hasil pengujian yang memastikan bahwa tidak adanya pertanyaan dari kuisioner sebagai instrument penelitian yang ambigu [20]. Suatu variabel dari instrimen penelitian dapat yang menunjukkan Cronbach Alpha > (lebih besar dari) 0.60 maka akan dinyatakan reabel. Untuk melakukan pengujian sehingga dapat menentukan reliabilitas dari setiap instrument akan menggunakan menggunakan software SPSS versi 21 sebagai alat untuk melihat hasil berupa tabel perolehan relibilitas setiap masing-masing variabel domain proses. Hasil rekapitulasi ujian reabilitas akan ditunjukkan pada tabel 3. berikut ini :

Tabel 3 Rekapitulasi Uji Reliabilitas

\begin{tabular}{ccl}
\hline $\begin{array}{c}\text { Variabel } \\
\text { Domain } \\
\text { Proses }\end{array}$ & $\begin{array}{l}\text { Cronbach's } \\
\text { Alpa }>0.6\end{array}$ & Keterangan \\
\hline EDM04 & 0.865 & $\begin{array}{l}\text { Sangat } \\
\text { Reliabel }\end{array}$ \\
\hline APO01 & 0.775 & Reliabel \\
\hline APO07 & 0.875 & $\begin{array}{l}\text { Sangat } \\
\text { Reliabel }\end{array}$ \\
\hline BAI08 & 0.837 & $\begin{array}{l}\text { Sangat } \\
\text { Reliabel }\end{array}$ \\
\hline
\end{tabular}

Sumber : Hasil pengolahan data 


\subsection{Analisis Domain COBIT 5}

1. Tingkat Kematangan Current Maturity Berikut ini grafik yang menunjukkan tingkatan setiap domain proses yang menjadi domain untuk dapat meningkatkan tata kelola teknologi informasi SMP Negeri Kota Lubuklinggau :

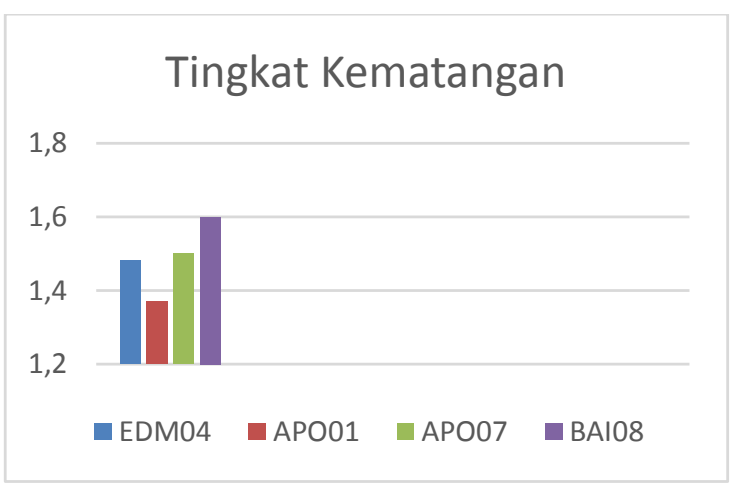

Gambar 4 Perbandingan Nilai Tingkat Kematangan Setiap Domain Sumber : Hasil pengolahan data

2. Gap Kesenjangan Level Kematangan Pada tabel dibawah ini memberikan gambaran penjelasan gap setiap domain proses dari tingkatan maturity level, dimana terdapat 4 (empat) domain proses terpilih yaitu APO07, EDM04, BAI08 dan APO01, domain proses tersebut telah teridentifikasi dapat meningkatkan tata kelola teknologi informasi SMP Negeri Kota Lubuklinggau :

Tabel 4 Tingkat Kematangan Domain Proses

\begin{tabular}{lccc}
\hline $\begin{array}{l}\text { Proses } \\
\text { Domai } \\
\mathrm{n}\end{array}$ & $\begin{array}{c}\text { Current } \\
\text { Maturit } \\
y\end{array}$ & $\begin{array}{c}\text { Expecte } \\
d\end{array}$ & Gap \\
Maturity & \\
\hline $\begin{array}{l}\text { EDM0 } \\
4\end{array}$ & 1.48 & 3 & 1.52 \\
\hline $\begin{array}{l}\text { APO0 } \\
1\end{array}$ & 1.37 & 3 & 1.63 \\
\hline $\begin{array}{l}\text { APO0 } \\
7\end{array}$ & 1.50 & 3 & 1.50 \\
\hline BAI08 & 1.60 & 3 & 1.40 \\
\hline
\end{tabular}

Sumber : Hasil pengolahan data

Berikut ini gambar gab kesenjangan level kematangan pada antara Current Maturit dan Expected Maturity pada setiap domain COBIT 5 :

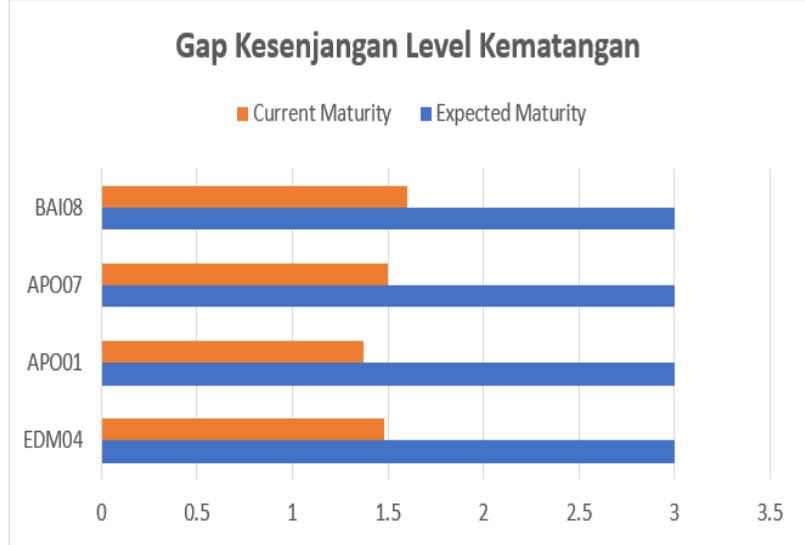

Gambar 5 Perbandingan Gap Kesenjangan Level Kematangan Sumber : Hasil pengolahan data

3. Gap Analisis Untuk Memperbaiki Gap Tingkat Kematangan

Perbaikan gap tingkat kematangan antara Current Maturity tata kelola teknologi informasi SMPN Kota Lubuklinggau dengan Expected Maturity yang diharapkan untuk dapat lebih meningkatkan level kematangan tata kelola IT. Setelah dilakukan pengumpulan data dengan melakukan wawancara terhadap beberapa kepala sekolah dari SMPN Kota Lubuklinggau disimpulkan bahwa kondisi tata kelola TI saat ini menunjukkan banyak kekurangan sehingga diharapkan tata kelola TI dapat lebih ditingkatkan pada kondisi yang berjalan secara standard dan dapat didokumentasikan didokumentasikan serta dapat memberikan efektivitas dan performa yang baik. Berdasarkan pernyataan tersebut maka setiap SMPN Lubuklinggau berharap tata kelola TI dapat ditingkatkan pada expected maturityl kematangan yang diharapkan pada level 3. Berikut ini tahapan yang berguna untuk dapat memperbaiki maturity level sehingga dapat lebih ditingkatkan yaitu dengan :

a. Proses perbaikan dilakukan sercara bertahap untuk mencapai tingkat kematangan yang paling yang 
diharapkan yaitu pada level 3 (Defined Prosess).

b. Atribut dengan tingkat kematangan saat ini didefinisikan berada pada level yang paling rendah secara berurutan yaitu APO01 Manage the IT Management Framework (Mengelola kerangka kerja manajeman TI), EDM04 Memastikan pengoptimalan sumber daya (Ensure Resource Optimisation) serta APO07 Mengolala sumber daya manusia (Manage Human Relations) medapat perhatian untuk dilakukan perbaikan sehingga tercapai keseimbangan tingkat kematangan setiap atribut domain proses.

c. Setelah atribut domain proses terpilih berada pada keseimbangan tingkat kematangan maka optimasi semua domain terpilih dan keseluruhan domain proses menjadi lebih maksimal dan dapat ditingkatkan pada level yang sama selanjutya yaitu level 2 (Repeatable but Intuitive).

Tata kelola IT pada SMPN di Kota Lubuklinggau harus dapat menutupi gap dari maturity level yang ada saat ini. Sehingga untuk keseluruhan sumber daya akan mampu mendukung seluruh proses penerapan teknologi informasi sehingga misi serta visi yang merupakan tujuan dari organisasi dari setiap SMPN Kota Lubuklinggau dapat tercapai. Gap yang ada akan diproses untuk dapat memenuhi tingkat optimalisasi tingkat kematangan dengan melakukan kegiatan sesuai denga standarisasi pada maturity level. Dari beberapa domain proses yaitu APO07, EDM04, BAI08 dan APO01 memiliki keadaan yang harus dipenuhi dengan deksipsi penjelasan sebagai berikut : a. EDM04 Ensure Resource Optimisation (Memastikan Pengoptimalan Sumber Daya)

Definisi dari EDM04 (Memastikan Pengoptimalan Sumber Daya) yaitu pastikan kemampuan yang memadai dan memadai yang terkait (orang, proses dan teknologi) tersedia untuk mendukung tujuan perusahaan secara efektif dengan biaya yang optimal [16].

Menurut Yudistira Dian Hastiti dan Lalang Erawan terdapat empat proses untuk dapat meningkatkan sumber daya diantaraya yaitu (1) Penetapan standar prosedur perandan tanggung jawan secara rinci (2) Perlu adanya penambahan personil yang berkompetensi dibidang TI (3) Melakukan penetapan kinerja secara detail guna memantau hasil kerja dan (4) Penetapan performa kinerja SDM sebagai peran yang membantu meningkatkan proses optimalisasi sumber daya [22].

b. APOO1 Manage the IT Management Framework (Mengelola kerangka kerja manajeman TI)

Definisi dari APO01 (Mengelola kerangka kerja manajeman TI) yaitu mengklarifikasi dan memelihara tata kelola misi dan visi TI perusahaan. Menerapkan dan memelihara mekanisme dan otoritas untuk mengelola informasi dan penggunaannya di perusahaan dalam mendukung tujuan tata kelola sejalan dengan prinsip dan kebijakan panduan [16].

Menurut Nanda Fiesta Farada, Andi Reza Perdanakusuma dan Suprapto terdapat tujuh proses untuk dapat meningkatka proses kelola kerangka kerja manajeman TI yaitu (1) Melakukan penilaian resiko TI dan analisis resiko, (2) Melakukan pendokumentasian terkait catatan kualitas dari target yang ditentukan, (3) Membuat matriks kontrol

dalam mengelola kerangka kerja manajemen TI, (4) Setiap standart atau SOP yang sudah ditetapkan, (5) Membuat catatan kualitas dari penerapan SOP, (6) Melakukan 
audit internal terhadap penerapan SOP dan (7) Setiap standart atau SOP yang sudah ditetapkan harus memiliki batasan kontrol [23].

c. APO07 Manage Human Relations (Mengolala sumber daya manusia)

Definisi dari APO07 (Mengolala sumber daya manusia) yaitu berikan pendekatan terstruktur untuk memastikan penataan, penempatan, hak keputusan, dan keterampilan sumber daya manusia yang optimal. Ini termasuk mengkomunikasikan peran dan tanggung jawab yang ditetapkan, rencana pembelajaran dan pertumbuhan, dan harapan kinerja, didukung oleh orang-orang yang kompeten dan termotivasi [16]. Sumber daya manusia menjadi salah satu penentu untuk dapat meningkatkan kemampuan organisasi secara efektif dan efisien sehingga membantu yang turut berdampak pada peningkatan kinerja lingkungan organisasi mereka selain dari infrastruktur TI dan manajemen TI [24].

Menurut Jons terdapat lima strategi pengembangan sumber daya manusia untuk dapat ditingkatkat diantaranya yaitu peningkatan melalui (1) pelatihan, (2) pendidikan, (3) pembinaan, (4) recruitment dan

(5) perubahan sistem [25].

BAI08 Manage Knowledge (Mengelola pengetahuan)

Definisi dari BAI08 (Mengelola kerangka kerja manajeman TI) yaitu pertahankan ketersediaan pengetahuan yang relevan, terkini, divalidasi, dan andal untuk mendukung semua kegiatan proses dan untuk memfasilitasi pengambilan keputusan. Merencanakan identifikasi, pengumpulan, pengorganisasian, pemeliharaan, penggunaan, dan pensiunnya pengetahuan. [16].

Menurut Suparto Darudiatodan Kevin Setiawan terdapat beberapa proses yang dapat dilakukan untuk kelola pengetahuan (knowledge) diantaranya yaitu (1) memastikan bahwa kelola pengetahuan dapat diterapkan pada tingkat operasional, (2) mengubah atau menerjemahkan tujuan kelola pengetahuan yang bersifat obyektif menjadi lebih konkrit dan nyata, dan (3) memaksimalkan memaksimalkan infrastruktur teknologi

\subsection{Pembahasan Hasil Penelitian}

Hasil penelitian diproses setelah dilakukan berbagai tahapan proses penelitian diantaranya penulis melakukan proses pengumpulan data dengan cara kuisioner dan dokumentasi, kemudian melakukan proses pemetaan doamin COBIT 5 untuk mendapatkan domain proses sebagai acuan penulis melakukan proses penentuan tingkat maturity level pata tata kelola TI untuk SMPN Kota Lubuklinggau serta menghasilkan daftar pertanyaan untuk kuisioner berdasarkan pemetaan domain proses COBIT 5 yang telah dilakukan. Proses selanjutnya memberikan hasil daftar kuisioner kepada responden, dalam penulisan ini penulis mengambil sample yang disajikan sebagai responden yaitu kepala sekolah, guru, staf dan siswa dengan jumlah 100 responden. Dalam pengambilan data penulis melakukan penyebaran kuisioner secara langsung ke 15 SMP Negri di Kota Lubuklinggau. Proportional random sampling merupakan teknik pengambilan sampel yang akan dilakukan pada penelitian ini, serta untuk melakukan pengumpulan data akan dilakukan dengan menggunakan kuisioner menggunakan pengukuran skala likert dan dokumentasi

Dari hasil pengujian yang telah dilakukan menggunakan aplikasi SPSS versi 21. Hasil dari pengolahan yang dilakukan mendapatkan pengujian reabilitas yang menunjukkan dari setiap variabel penelitian memiliki nilai yang sangat reliabel yang dapat dilihat pada Tabel 3 dengan dihasilkan dari nilai cronbach's alpha pada domain 
proses terpilih diantaranya yaitu proses EDM04 (Ensure Resource Optimisation) yaitu 0.914 dan menunjukkan nilai cronbach's alpha lebih dari nilai koefisien yaitu lebih besar dari 0.6. Uji reliabilitas instrumen dalam penelitian ini menggunakan metode alpha cronbach $(\alpha)$ karena instrumen penelitian ini berbentuk angket dan skala bertingkat.

Selain melakukan uji reliabilitas juga dilakukan pengujian validasi pada setiap item pertanyaan dalam kuisioer, setelah melakukan penyebaran pada 15 SMP Negeri di Kota Lubuklinggau dengan jumlah responden penelitian sebanyak 100 responden dan diperoleh data yang diuji, setelah dilakukan pengujian didapatkan semua item variabel dinyatakan valid. Pada semua indikator dalam setiap variabel menunjukkan rata-rata nilai lebih besar dari $\mathrm{r}_{\text {tabel }} \quad 0.195$ sehingga semua variabel memenuhi kreteria untuk dapat digunakan sebagai acuan melakukan melakukan peningkatan maturity level pada TI di SMPN Kota Lubuklinggau.

Berdasarkan hasil penilaian penentuan level kematangan pada beberapa domain yang terpilih diketahui bahwa untuk domain yang memiliki maturity level tertinggi yaitu pada domain BAI08 (Manage Knowledge) dengan nilai maturity level sebesar 1.60 pada level Repeatable but Intuitive, Tingkat Kematangan Kedua yaitu domain proses APO07 (Manage Human Resources) dengan nilai maturity level sebesar 1.50, Tingkat Kematangan Ketiga yaitu domain proses EDM04 (Ensure Resource Optimisation) dengan nilai maturity level sebesar 1.48, dan tingkat kematangan terendah yaitu domain proses APO01 (Manage the IT management framework) dengan nilai maturity level sebesar 1.37.

\section{KESIMPULAN}

Pada penelitian ini telah dilakukan proses analisis untuk dapat mengetahui tingkatan maturity level yang berguna sebagai salah satu acuan untuk dapat mengetahui serta meningkatkan maturity level tata kelola TI di SMPN Kota Lubuklinggau. COBIT 5 digunakan untuk melakukan proses identifkasi tingkat maturity level. Berikut ini kesimpulan yang didapat setelah mengetahui hasil dari proses penelitian diantaranya yaitu :

1. Hasil dari proses pemetaan domain proses COBIT 5, terdapat 4 doamin proses terpilih yang dapat digunakan untuk mengetahui maturity level teknologi yang telah diterapkan pada SMP Negeri Kota Lubuklinggau, domain tersebut diantaranya yaitu APO07, EDM04, BAI08 dan APO01.

2. Domain proses BAI08 (Manage Knowledge) merupakan domain dengan tingkatan maturity level tertinggi yaitu dengan nilai 1.60 pada level Repeatable but Intuitive, dan tingkat kematangan terendah yaitu domain proses APO01 (Manage the IT management framework) dengan nilai 1.37.

3. Maturity level atau tingkat kematangan pada tata kelola Teknologi Informasi di SMPN Kota Lubuklinggau yaitu dengan nilai maturity level sebesar 1.48 yang teridentifikasi pada tingkatan level 1 dengan deksirpsi penerapan teknologi informasi dilakukan secara Ad Hoc.

\section{SARAN}

Dengan dilakukannya penelitian yaitu konsep tata kelola TI yang berguna untuk dapat mengetahui serta lebih meningkatkan maturity level di SMPN Kota Lubuklinggau. Maka dari hasil yang diperoleh penulis memberikan saran yang ingin disampaikan yaitu : 
1. Tata kelola teknologi informasi setiap sekolah terdapat perbedaan, sehingga perlu adanya peraturan dasar yang membawahi setiap sekolah untuk dapat meningkatkan tata kelola teknologi.

2. Pemerintah perlu lebih dapat memfasilitasi baik dari sumber daya manusia ataupun sarana dan prasarana untuk dapat memaksimalkan proses pembelajaran setiap sekolah dengan menerapkan teknologi yang membantu sekolah sehingga tata kelola teknologi informasi dapat lebih meningkat.

3. Penelitian ini dapat dijadikan refrensi untuk penelitian selanjutnya dengan melakukan pengembangan variabel yang menjadi domain terpilih sehingga menghasilkan konsep tata kelola teknologi informasi yang lebih baik lagi.

\section{DAFTAR PUSTAKA}

[1] D. Antoni, Apriliani, M. I. Herdiansyah, and M. Akbar, "Critical factors of transparency and trust for evaluating e-government services for the poor," Proc. 2nd Int. Conf. Informatics Comput. ICIC 2017, vol. 2018-January, no. November, pp. 1-6, 2018.

[2] Peraturan Pemerintah RI, "Pengelolaan Dan Penyelenggaraan Pendidikan," p. 210, 2010.

[3] H. Kusbandono and D. Ariyadi, "Rekomendasi Tata Kelola Aset Ti Berdasarkan Cobit 5," Simetris J. Tek. Mesin, Elektro dan Ilmu Komput., vol. 9, no. 2, pp. 10151020, 2018.

[4] F. Rahmadayanti, W. Cholil, and L. Atika, "Optimalisasi Tata Kelola Teknologi Informasi Menggunakan Cobit 5 (Studi Kasus Stt Pagar Alam)," J. Bina Komput., vol. 1, no. 2, pp. 116-121, 2019.
Jonathan, "Model Konseptual Penerapan IT Governance Di Lembaga Keuangan Mikro Berbasis COBIT 5 Framework," pp. 8-9, 2018.

[6] A. K. Darmawan and A. Dwiharto, "Pengukuran Capability Level Kualitas Layanan E-Government Kabupaten Pamekasan Menggunakan Framework COBIT 5.0," INTENSIF J. Ilm. Penelit. dan Penerapan Teknol. Sist. Inf., vol. 3, no. 2, p. 93, 2019.

[7] Elly and F. Halim, "Evaluasi Tatakelola Infrastruktur Ti Dengan Framework Cobit 5 ( Studi Kasus: Stmik - Stie Mikroskil )," Sebatik, vol. 5, pp. 74-82, 2016.

[8] R. S. Kharisma et al., "Pengukuran Tingkat Kematangan Tata Kelola Ti Dengan Menggunakan Control Objective Plan And Organize Pada Framewrok Cobit5," pp. 1-12, 2012.

[9] Peraturan Kementerian Pendidikan Dan Kebudayaan, "Standar Proses Pendidikan Dasar Dan Menengah," vol. 2011, pp. 1-6, 2012.

[10] Peraturan Pemerintahan RI, "Sistem Pendidikan Nasional," no. Mm, pp. 1-18, 2003.

[11] S. N. S. Berlianna, "Evaluasi Tingkat Kapabilitas Sumber Daya Teknologi Informasi Pada Institut Teknologi Nasional Malang Menggunakan Kerangka Kerja Cobit 5, $J$. Pengemb. Teknol. Inf. dan Ilmu Komput. Univ. Brawijaya, vol. 2, no. 10, 2018.

[12] W. Cholil, E. Yulianingsih, and A. A. Diharja, "Audit Tata Kelola Sistem Kepegawaian Dinas Tenaga Kerja dan Transmigrasi Provinsi Sumatera Selatan dengan Kerangka Kerja COBIT Versi 5," Thesis Univ. Bina Darma, Palembang, vol. 5, pp. 1-9, 2013. 
[13] M. Alhan, "Perancangan It Governance Menggunakan Cobit Versi 4.1," vol. X, no. 2, pp. 11-22, 2011.

[14] L. I. Sari and L. Probonegoro, Wishnu Aribowo, "Audit Sistem Informasi Terhadap Penilaian Teknologi Informasi Maskapai ABC Menggunakan Cobit 4 . 0," Knsi 2018, pp. 700-704, 2018.

[15] I. G. Institute, Control Objectives, COBIT 3 rd Edition. 2000.

[16] ISACA, "IT Governance \& The COBIT 5.0 Framework," 2012.

[17] I. G. Institute, IT Governance Implementation Guide 2nd. 2007.

[18] Sugiyono, Metode Penelitian Administrasi. Bandung: Alfabeta, 2018.

[19] F. Purwaningtias, M. I. Hardiansyah, and S. Rizal, "AUDIT TATA KELOLA IT ( IT GOVERNANCE ) PADA POLITEKNIK SEKAYU MENGGUNAKAN COBIT 5," 2016.

[20] A. Prasetyo and N. Mariana, "Analisis Tata Kelola Teknologi Informasi ( It Governance ) pada Bidang Akademik dengan Cobit Frame Work Studi Kasus pada Universitas Stikubank Semarang," $J$. Teknol. Inf. Din., vol. 16, no. 2, pp. 139-149, 2011.

[21] Irfan, "Analisis Kebutuhan Stakeholder Dalam Mengembangkan Model Tata Kelola TI MEngenai Transparansi Pengadaan Sistem Informasi Pada Pemerintah Kota Makassar Berdasarkan Cobit 5," Pros. - Semin. Nas. Ilmu Komput., no. 20, pp. 1-6, 2014.

[22] Y. D. H. dan L. Erawan, "Analisis Tata Kelola Optimalisasi Sumber Daya Sistem Informasi Manajemen Jembatan Timbang (Edm04) Berdasarkan Kerangka Kerja Cobit 5
Pada Dinas Perhubungan

Komunikasi Dan Informatika

Provinsi Jawa Tengah," Techno COM, vol. 15 , no. 2, pp. 170-176, 2016.

[23] N. F. Farada and A. R. Perdanakusuma, "Evaluasi Tingkat Kapabilitas Tata Kelola Teknologi Informasi dengan Kerangka Kerja COBIT 5 pada Proses APO01 dan APO07 di Dinas Komunikasi dan Informatika Provinsi Jawa Timur," vol. 3, no. 6, pp. 6016-6025, 2019.

[24] D. Antoni and F. Jie, "The relationship between IT capability and organisational environment performance: A conceptual framework," no. February 2016, 2012.

[25] B. K. dan Nurhajati, "Pengaruh Pengembangan Sumber Daya Manusia Dan Motivasi Terhadap Kinerja Pegawai Dinas Pariwisata Kota Batu,” vol. II, pp. 85-97, 2017. 